Diabetología 8, 29-36 (1972)

(C) by Springer-Verlag 1972

\title{
Pharmacological Study of a New Hypoglycaemic Sulphonamide: Glisoxepid (RP 22410)
}

\author{
A. Loubatit̀res, M.M. Mariani, G. Ribes, R. AlRid and H. Agot \\ Faculté de Médecine, Institut de Biologie, Montpellier, France \\ Received: October 1, 1971, accepted: December 6, 1971
}

\begin{abstract}
Summary. Glisoxepid or RP 22410 is a new very active hypoglycaemic sulphonylurea. In the normal conscious dog, RP 22410 administered intravenously was 81 or 131 times more active than tolbutamide, depending on whother the dose is expressed in grams or in moles. The hypoglycaemic effect did not oecur in the totally pancreatectomized dog. - RP 22410 stimulated insulin secretion. In vivo in the anaesthetized or conscious dog, the action of the drug (whether it be administered intravenously or orally) resulted in a rapid and considerable increase of the amount of insulin secreted by the pancreas. This action lasted several hours. In vitro the direct action of the product on the pancreas was demonstrated on the isolated and perfused rat pancreas, even at very low concentrations. - In the mouse, prolonged oral administration of RP 22410 stimulated neogenesis of the islets of Langerhans and of the beta cells. It therefore possesses betacytotrophic action.
\end{abstract}

Etude pharmacologique d'un nouveau sulfamide hypoglycémiant: le glisoxepid̀ ( $R P$ 22410)

Résumé. Le glisoxepid ou RP 22410 est un nouveau sulfonylurée hypoglycémiant très actif. Chez le chien normal éveillé, administré par voie intraveineuse, il est 81 ou 131 fois plus actif que le tolbutamide, suivant que les doses sont exprimées on poids ou en moles. Cette action hypoglycémiante ne se manifeste pas chez le chien totalement dépancréaté. - Ce produit stimule la sécrétion d'insuline. In vivo chez le chien anesthésié ou éveillé, l'action du produit (que celui-ci soit administré par voie intraveineuse ou par voie digestive) se traduit par une augmentation rapide et considérable de la quantité d'insuline sécrétée par le pancréas. Cette action se prolonge pendant plusieurs heures. In vitro l'action directe du produit sur le pancréas a été démontrée sur le pancréas isolé et perfusé du rat, même à très faibles concentrations. - Chez la souris lo RP 22410 administré chroniquement per os stimule la néogénèse des îlots de Langerhans et des cellules bêta. Il est donc doué de l'action bêtacytotrophe.

Pharmakologische Studie über das neue blutzucleersenkende Sulfonamid Glisoxepid RP 22410

Zusammenfassung. Glisoxepid oder RP 22410 ist ein neuer, stark aktiver, blutzuckersenkender Sulfonylharnstoff. Je nachdem ob die Dosen in Gewichten oder Mol ausgedrückt werden, ist er am wachen Hund bei intravenöser Applikation 81 bzw. 131mal aktiver als Tolbutamid. Die blutzuckersenkende Wirkung zeigt sich nicht am vollständig pankreatektomierten Hund. - Diese Substanz stimuliert die Insulinselkretion. In vivo zeigt sich ihre Wirkung am anästhesierten oder wachen Hund in einer schnellen und beträchtlichen Erhöhung der vom Pankreas sezernierten Insulinmenge unabhängig davon ob sie intravenös oder per os verabreicht wird. Diese Wirkung bleibt über mehrere Stunden bestehen. In vitro wurde die direkte Wirkung der Substanz auf den isolierten und perfundierten Pankreas der Ratte auch in sehr geringen Konzentrationen nachgewiesen. - Bei der Maus stimuliert RP 22410 bei chronischer Verabreichung per os die Neubildung von Langerhansschen Inseln und B-Zellen. Sie besitzt daher eine betacytotrophe Wirkung.

Key words: Insulin secretion in vivo and in vitro, hypoglycaemic sulphonamide, oral antidiabetic substances, RP 22410, tolbutamide, insulin secretion stimulator, islets of Langerhans, islet development, beta cells, betacytotrophic action, Glisoxepid.
RP 22410 or BS 4231 Glisoxepid or $4-(4-\beta-(5-$ methyl-isoxazole - 3 - carboxamido)-ethyl-benzol-sulfonyl)-1,1-hexamethylene-semicarbazide) is a new and very active hypoglycaemic sulphonamide. This publication gathers various experiments that we have carried out with this substance in order to demonstrate its effect and its mode of action. Some results have already been published [14-15].

- Some experiments were carried out on normal dogs, conscious or anaesthetized, and also on pancreatectomized dogs.

- Others were carried out on an entire isolated and perfused rat pancreas.

- Finally we have studied the consequences of a prolonged treatment of RP 22410 on the development of the islets of Langerhans in the mouse.

\section{Studies in the dog}

\section{A) Experimental conditions and techniques used}

We have operated on mongrels whose weight was 10 to $18 \mathrm{~kg}$. The experiments were carried out either on normal animals or on totally pancreatectomized animals.

The normal dogs were kept fasting for $18 \mathrm{~h}$ before and during the whole experiment.

In the case where the animal was anaesthetized, it received pentobarbital (Nembutal) at a dose of $30 \mathrm{mg} /$ $\mathrm{kg}$ intravenously.

The pancreatectomized dogs underwent a total pancreatectomy several days before the experiment. They were regularly surveyed, fed and treated with insulin; the administration of insulin was stopped $24 \mathrm{~h}$ before the experiment began, and all caloric intake was stopped $18 \mathrm{~h}$ before. 
RP 22410 was administered using two methods:

- by intravenous injection into a peripheral vein. The substance was therefore made soluble with $1 \mathrm{~N} \mathrm{NaOH}$, and was injected in a solution of $0.9 \%$ $\mathrm{NaCl}$.

- orally, in the form of a powder.

The blood samples necessary for blood glucose determination were taken from peripheral veins. The determinations were made either on separate samples taken from a jugular vein (in the conscious animals) or in a continuous way from the femoral vein after heparinization (in the anaesthetized animals).

The blood glucose level was measured with the Technicon Auto-Analyzer, using the potassium-ferricyanide method on haemolyzed blood [1].

The blood samples necessary for the determination of insulin were obtained:

- either peripherally from the jugular vein

- or from the pancreatico-duodenal vein directly at its exit of the pancreas. In order to do this, a Tshaped piece of glass was included in the pancreatico-duodenal vein sectioned close to its junction with the portal vein.

The assay of insulin (IRI) was carried out with the radio-immunological $B$ method of Hales and Randle [4].

\section{B) Results}

1. Action of RP 22410 on the glycaemia of normal conscious dogs after intravenous administration.

In Fig. 1 are shown the results obtained when increasing doses of RP $22410(0.02 \mathrm{mg} / \mathrm{kg}, 0.04 \mathrm{mg} / \mathrm{kg}$,

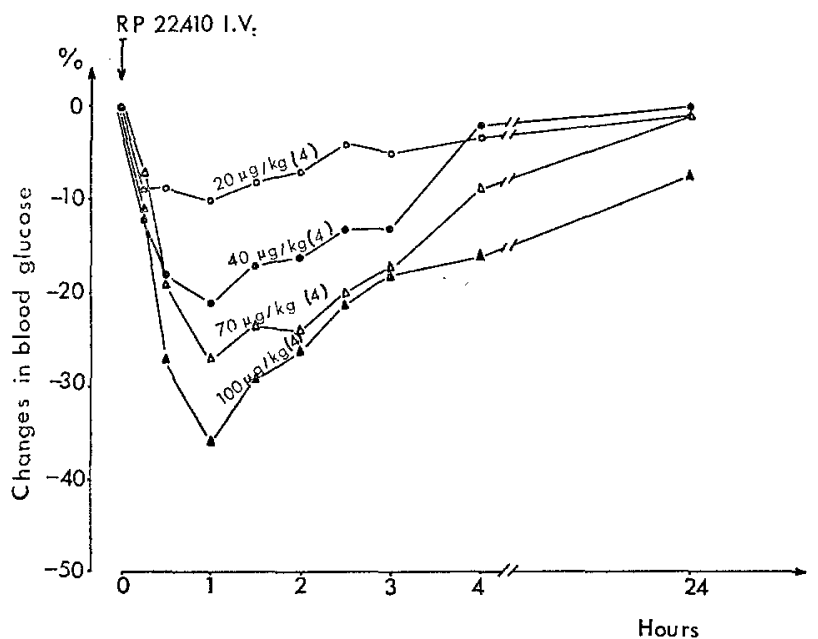

Fig. 1. Action of increasing doses of RP 22410, administered intravenously on the blood glucose of the normal conscious dog. Each point represents the average of the values obtained in several dogs. The number of animals used for the establishment of each curve is indicated in parenthesis

$0.07 \mathrm{mg} / \mathrm{kg}, 0.1 \mathrm{mg} / \mathrm{kg}$ ) were administered. We noticed that the hypoglycaemic effect of the drug occurred immediately, it reached a maximum in one hour. As the dose administered increased, this effect became more intense and more prolonged.

The threshold dose (dose which lowers the glycemia about $10 \%$ ) was approximately $0.02 \mathrm{mg} / \mathrm{kg}$.

The comparison of the effects of $R P 22410$ and tolbutamide on the glycaemia of normal dogs was carried out using the same experimental conditions.

Tolbutamide (1-butyl-3p-tolyl-sulfonylurea) was administered intravenously. The doses injected are higher than those injected during the trials carried out with RP 22410 . The threshold dose of tolbutamide is about $2 \mathrm{mg} / \mathrm{kg}$.

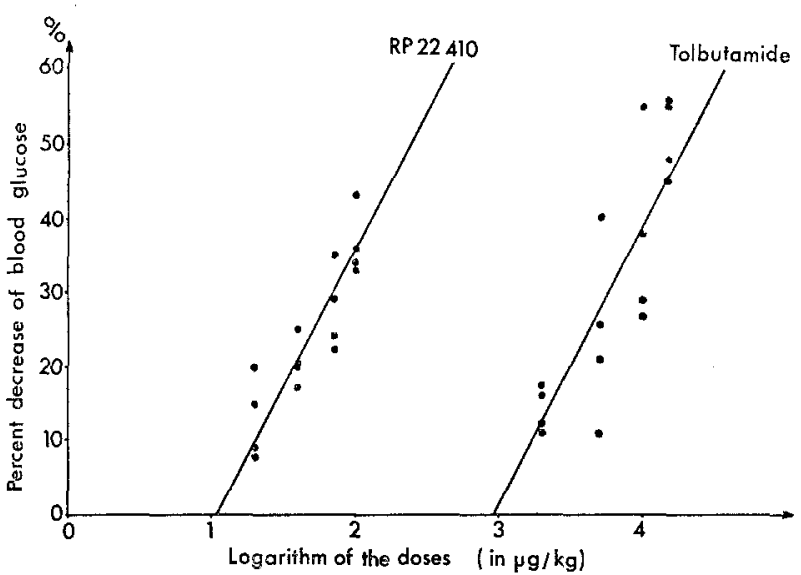

Fig. 2. Comparative study of RP 22410 and tolbutamide with regard to their relative hypoglycaemic potency in the normal conscious dog after intravenous administration. The abscissa represent the logarithms of the doses (expressed in $\mu \mathrm{g} / \mathrm{kg}$ ) and the ordinates represent the percentages of blood glucose drop. Each point represents the maximal blood glucose drop obtained in each animal after the administration of one dose

Fig. 2 represents this comparative study. For each of the two hypoglycaemic sulphonamides, four doses were injected, four animals being used for each dose. The doses of RP 22410 were $0.02 \mathrm{mg} / \mathrm{kg}, 0.04 \mathrm{mg} / \mathrm{kg}, 0.07$ $\mathrm{mg} / \mathrm{kg}, 0.1 \mathrm{mg} / \mathrm{kg}$ and those of tolbutamide: $2 \mathrm{mg} / \mathrm{kg}$, $5 \mathrm{mg} / \mathrm{kg}, 10 \mathrm{mg} / \mathrm{kg}, 15 \mathrm{mg} / \mathrm{kg}$.

The comparison of the two drugs was performed according to the parallel line assay method [2]. The analysis of the results permits the following conclusions: the slopes of the two lines are not significantly different $\left\{F\left(\frac{1}{28}\right)<1\right\}$. The logarithm of the relative potency of RP 22410 in relation to that of tolbutamide (measured by the horizontal distance between the two lines) was $\mathrm{M} \pm \mathrm{sM}=1.91 \pm 0.144$ this corresponded to a relative potency of 81 for RP 22410 in relation to tolbutamide with the $95 \%$ confidence limits: 58 and 113 .

In our experimental conditions RP 22410 showed itself therefore, to be on the average 81 times more active than tolbutamide when the doses were evaluated by weight; when the doses were expressed in moles it was 131 times more active. 
2. Action of RP 22410 on the glycaemia of the conscious dog when the product is administered "per os".

It was important to know whether the substance was absorbed by the digestive tract and whether therefore, the hypoglycaemic action of the substance could manifest itself when given orally.

Chosen doses of RP 22410 were put in capsules, these were placed in the mouth of the animal who swallowed them. The doses used were $0.025 \mathrm{mg} / \mathrm{kg}$, $0.05 \mathrm{mg} / \mathrm{kg}, 0.1 \mathrm{mg} / \mathrm{kg}, 1 \mathrm{mg} / \mathrm{kg}$. The results of these experiments, carried out on 22 dogs, are shown in Fig. 3.

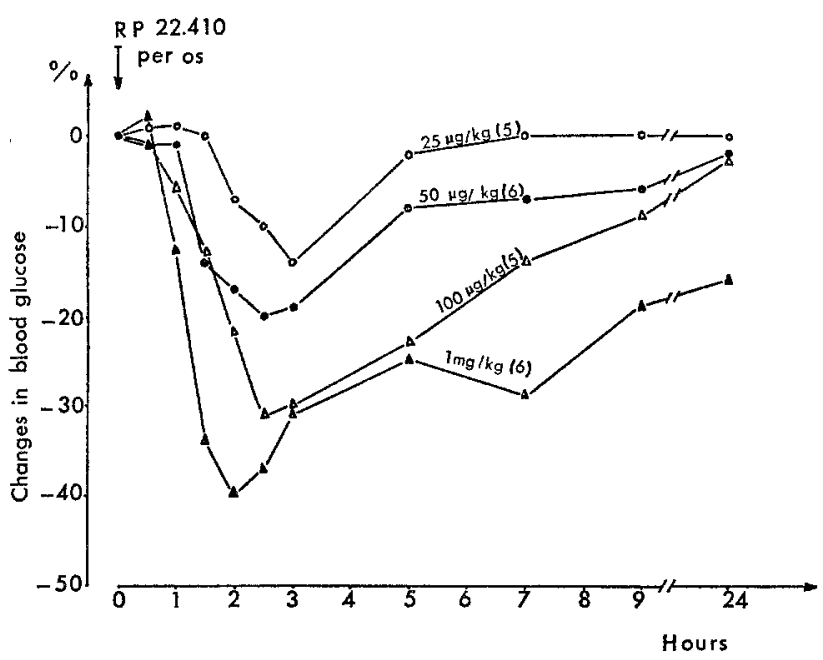

Fig. 3. Action of increasing doses of RP 22410, administered orally on the blood glucose of the normal conscious dog. Each point represents the average of the values recorded in several dogs. The number of animals used for the establishment of each curve is indicated in parenthesis

Hypoglycaemia was manifest after a latent period of 30 to $60 \mathrm{~min}$, according to the dose administered; the maximal effect being attained between two and three hours. As the dose increased, the hypoglycaemic action became more intense and more prolonged. For the dose of $1 \mathrm{mg} / \mathrm{kg}$, this activity continued for more than $24 \mathrm{~h}$. Therefore, it is certain that the substance was well absorbed by the digestive system and that it manifested its hypoglycaemic action when administered this way.

A comparison of the hypoglycaemic activity of $\mathrm{RP}$ 22410 after oral administration and after intravenous injection was carried out. The values of glycaemic drop (evaluated in percentages in relationship to the starting glycemia) for the various doses administered are shown in Table 1. After analysis of the results, there does not appear to be a significant difference between the slopes of the two lines obtained $\left\{F\left(\frac{1}{28}\right)<<1\right\}$. The logarithm of the relative potency of $\mathrm{RP} 22410$ administered intravenously in relationship to the product administered per os was: $M \perp \mathrm{s}_{M}=0.028 \pm 0.119$, which corresponds to a relative potency of 1.067 for intra- venous $R P 22410$ in relationship to oral $R P 22410$, with the $95 \%$ confidence limits 0.81 and 1.4 .

In our experimental conditions, $R P 22410$ therefore displays a similar hypoglycaemic activity when it is administered orally and intravenously.

Table 1. Percentages of the blood glucose drop registered after intravenous and oral administration of RP 22410 at various doses. Each value represents the maximal blood glucose drop obtained in each animal after an administration of one dose

\begin{tabular}{lrrrrrrr}
\hline \multicolumn{2}{c}{$\begin{array}{l}\text { RP 22410 I. V. } \\
\text { doses in } \mu \mathrm{g} / \mathrm{kg}\end{array}$} & & \multicolumn{4}{c}{$\begin{array}{l}\mathrm{RP} 22410 \text { per os } \\
\text { doses in } \mu \mathrm{g} / \mathrm{kg}\end{array}$} \\
\hline 20 & 40 & 70 & 100 & & 25 & 50 & 100 \\
\hline-15 & -25 & -24 & -34 & -18 & -21 & -33 \\
-20 & -17 & -35 & -43 & -9 & -28 & -25 \\
-9 & -20 & -22 & -36 & -23 & -31 & -39 \\
-8 & -20 & -29 & -33 & -15 & -18 & -39 \\
& & & & -12 & -17 & -35 \\
\end{tabular}

3. Absence of action of $R P 22410$ on glycaemia in the totally pancreatectomized dog.

It was important to know whether the hypoglycaemic action of this substance was due to the same mechanism as that demonstrated for the other hypoglycemic sulphonamides, that is to say, a stimulation of the beta cells of the islets of Langerhans and, consequently, the liberation of insulin.

To demonstrate this, we experimented on totally pancreatectomized dogs in comparison with normal dogs; in both groups the animals were conscious. The dose of RP 22410 administered was $0.1 \mathrm{mg} / \mathrm{kg}$ intravenously. According to our results, RP 22410 administered to totally pancreatectomized dogs has no action whatsoever on the blood glucose.

4. Action of RP 22410 on the secretion of insulin in the anaesthetized dog; the product being administered intravenously and the insulinaemia being measured in the pancreatico-duodenal venous blood.

We experimented on five normal dogs that received RP 22410 intravenously in a dose of $0.5 \mathrm{mg} / \mathrm{kg}$. Fig. 4 shows in its upper half the changes of blood glucose and in its lower half the variations of the plasma insulin output rate. RP 22410 stimulated the secretion of endogenous insulin and increased the basal insulin secretion by $300 \%$. The quasi-immediate stimulation increased during one hour, reached a maximum and then progressively decreased. However, the insulin secretion remained higher than the starting (basal) secretion during the five hours of the experiment. This basal secretion was, on an average, $217 \pm 41 \mathrm{ng} / \mathrm{min}$ which corresponds to $5425 \pm 625 \mu \mathrm{U} / \mathrm{min}$.

5. Action of RP 22410 on insulin secretion in the conscious dog; the product being administered "per os" and the insulinaemia being measured in a peripheral vein.

Six experiments were carried out during which the animals received, per os one dose of $1 \mathrm{mg} / \mathrm{kg}$ of the 
product. The curves represented in Fig. 5 express the results that were obtained.

The administration of the product per os was followed by an increase of the peripheral insulinaemia which reached a maximum between $11 / 2$ and $2 \mathrm{~h}$ and then remained higher than the starting value during the nine hours of the experiment.

This experiment demonstrated that the administration of RP 22410 per os provoked an abundant
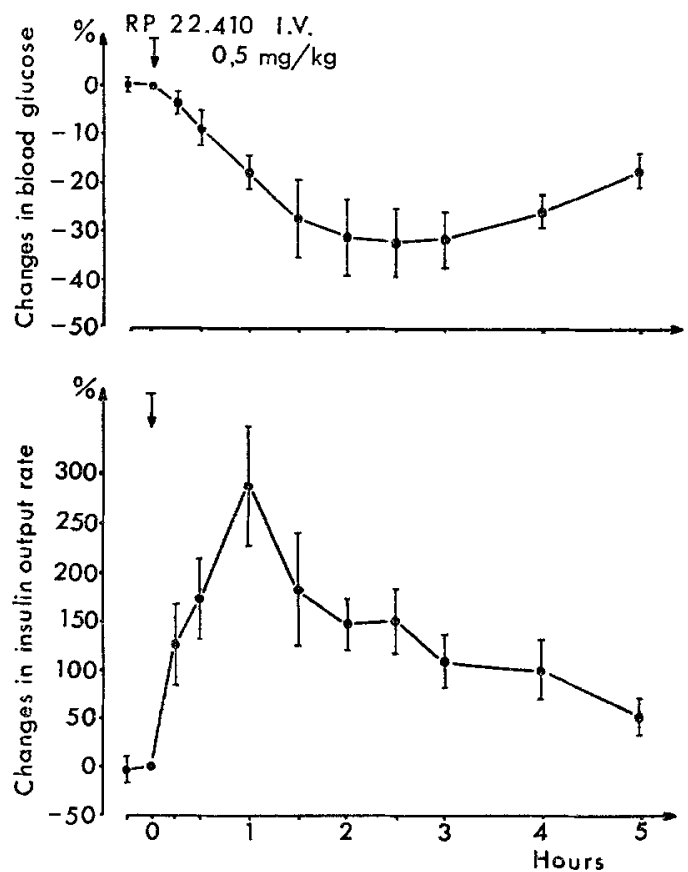

Fig. 4. Changes of the blood glucose and of the insulin secretion rate in the pancreatico-duodenal venous blood in 5 anaesthetized dogs who had received $0.5 \mathrm{mg} / \mathrm{kg}$ of RP 22410 intravenously. The changes are estimated in percentages in relationship to the value at time zero. Each point represents the average of the values and carries the standard error of the mean

insulin secretion (measurable in a peripheral vein) that lasted several hours in the experimental conditions used.

6. Effects of $R P 22410$ on insulin secretion in the conscious dog; the product being administered "per os" and the insulinaemia being measured in the pancreaticoduodenal venous blood.

In these experiments, the animals were prepared the previous day. The apparatus allowing direct sampling in the pancreatico-duodenal vein was put in place aseptically, the animal being anaesthetized with pentobarbital. This animal was then placed in a cage and the following day received RP 22410 orally in one dose of $1 \mathrm{mg} / \mathrm{kg}$. In this series of experiments the animals were unfed for about $30 \mathrm{~h}$ at the time of the administration of RP 22410 .

Three animals were placed under the same experimental conditions. The curves of blood glucose and insulinaemia obtained for each one of them are shown in Fig. 6. It can be seen that in the conscious dog, with blood being taken directly from the exit of the pancreas, RP 22410 acted as a strong insulin-secreting agent whose effects lasted for 8 to $10 \mathrm{~h}$.

The variations that occurred in the speed of action were probably secondary to variations in the intestinal absorption rate of the product. We were also able to show that during these experiments there was a close

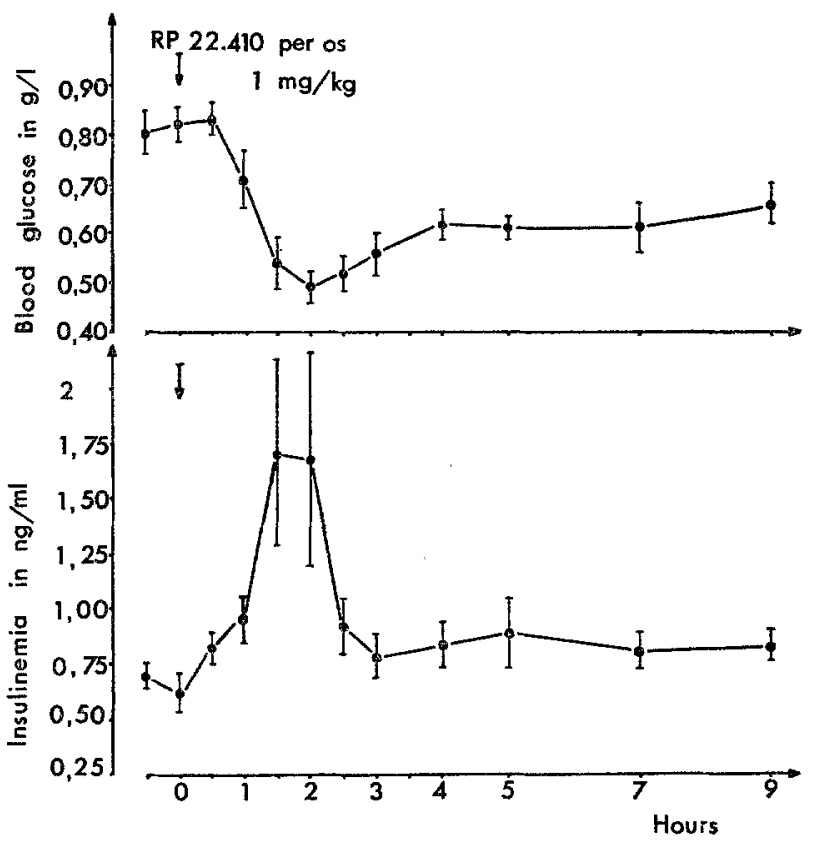

Fig. 5. Blood glucose and insulinaemia in the peripheral venous blood of 6 normal, conscious dogs after oral administration of RP 22410 (1 mg/kg). Each point represents the average of the values and carries the standard error of the mean. The concentration of plasma insulin is evaluated in $\mathrm{ng} / \mathrm{ml}$. According to the biological activity equivalence: $1 \mathrm{ng}$ of dog insulin corresponds on an average to $25 \mu \mathrm{U}$

correlation between the secretion of insulin and the changes in blood glucose. For example, the animal that produced insulin secretion peak in the first hour was also the one in which the blood glucose dropped most rapidly.

7. The potentiating action of $R P 22410$ on the hypoglycaemic effects of insulin; the phenomenon being studied in the pancreatectomized dog.

We know that the hypoglycaemic sulphonamides pre. viously described are capable of potentiating the hypoglycaemic effects of injected insulin, this phenomenon was demonstrated by experimenting on totally pancreatectomized dogs.

The experiments with RP 22410 were carried out on six dogs pancreatectomized 15 to 30 days before and treated correctly with insulin so as to control diabetes.

Two trials were performed on the same animal at 
a $24 \mathrm{~h}$ interval and under the same experimental conditions. The animal received no insulin within the preceeding $24 \mathrm{~h}$ and was fasted for $18 \mathrm{~h}$. During the first trial, each animal received an intravenous test dose of insulin (between $0.25 \mu \mathrm{U} / \mathrm{kg}$ and $0.5 \mu \mathrm{U} / \mathrm{kg}$ ) in order to determine its hypoglycaemic effect over $7 \mathrm{~h}$. During the second trial the same dose of insulin was administered under the same conditions, but in addition, immediately before the experiment the animal received RP 22410 at a dose of $1 \mathrm{mg} / \mathrm{kg}$ intravenously.

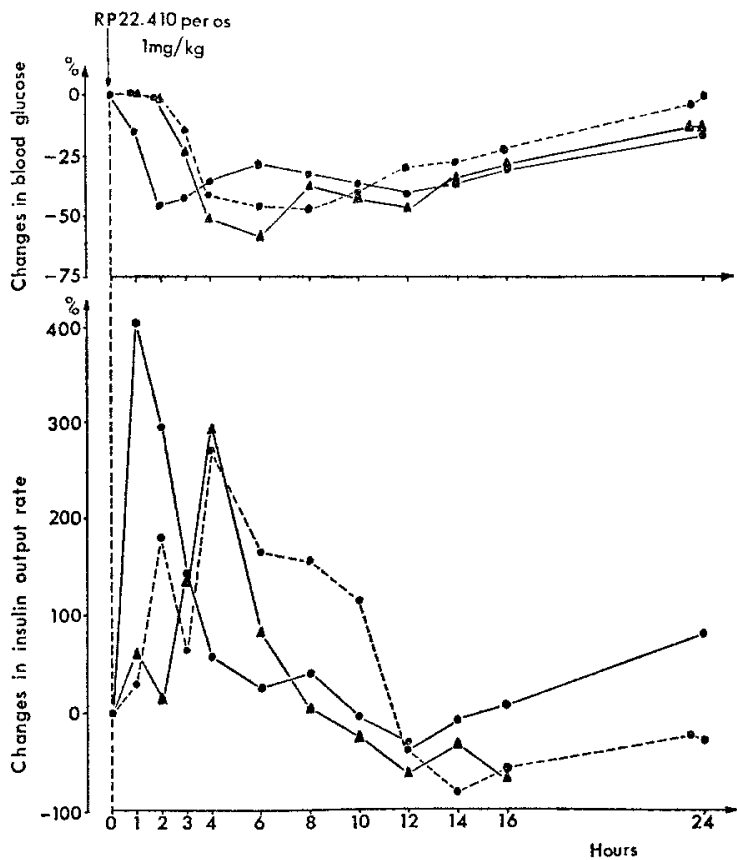

Fig. 6. On this graph are represented the changes in the blood glucose and the insulin secretion rate in the pancreatico-duodenal venous blood after oral administration of $1 \mathrm{mg} / \mathrm{kg}$ RP 22410 to three conscious dogs having a catheter in the pancreatico-duodenal vein. The changes are estimated in percentages in relationship to the value at time zero

Although the area of hypoglycaemia measured in the presence of RP 22410 was greater on the average than that measured with insulin alone, the calculations did not permit us to assert that the two areas were significantly different.

\section{Study on the isolated and perfused rat pancreas}

\section{A) Technique}

The preparation of the isolated and perfused rat pancreas allowed us to explore the direct effects of RP 22410 on insulin secretion from the endocrine pancreas.

The technique used has been previously described in detail [16]. The pancreas freed of all neighbouring tissues was perfused in an open circuit with KrebsRinger bicarbonate buffer $(\mathrm{pH} \simeq 7.3)$, bubbled at atmospheric pressure with a gas mixture $\left(93 \% \mathrm{O}_{2}\right.$,
$7 \% \mathrm{CO}_{2}$ ). This solution contained purified beef albumin $(2 \mathrm{~g} / \mathrm{l})$ and glucose $(1.5 \mathrm{~g} / \mathrm{l})$.

In all our experiments there was an adaptation period of $30 \mathrm{~min}$ between the start of the perfusion and the first sample of perfusate for insulin assay. A second sample was taken $15 \mathrm{~min}$ later. These two samples, corresponding to a control period, enable us

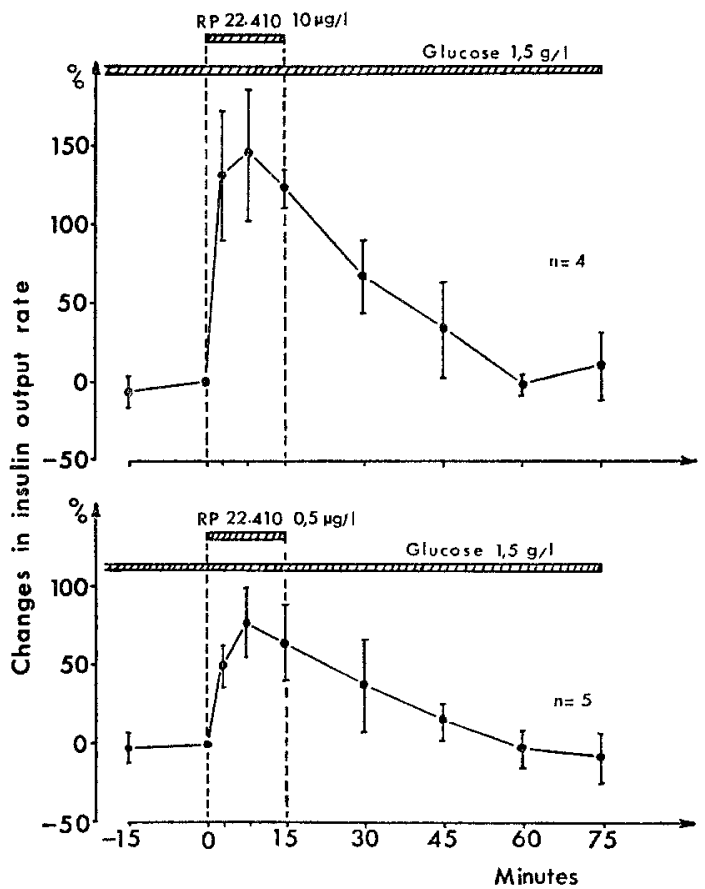

Fig. 7. Changes in the insulin secretion rate provoked by RP 22410 on the isolated perfused rat pancreas. The product was introduced into the perfusion medium in concentrations of $10 \mu \mathrm{g} / \mathrm{l}$ and $0.5 \mu \mathrm{g} / \mathrm{l}$ for $15 \mathrm{~min}$ starting at time zero. The variations are evaluated in percentages in relationship to the value at time zero. Each point represents the average of the values obtained and carries the standard error of the mean. The number of perfusions is indicated for each series of experiments

to know the basal insulin secretion rate of each individual organ before treatment. RP 22410 was then infused at a constant rate for $15 \mathrm{~min}$. Samples were taken during the infusion of drug and for $60 \mathrm{~min}$ later.

The insulin was assayed according to the radio-immunological method B of Hales and Randle [4], the biological activity of the rat insulin used for the standard curve was $19 \mu \mathrm{U} / \mathrm{ng}$.

\section{B) Results}

The experiments were performed using concentrations of RP 22410 between $50 \mu \mathrm{g} / 1$ and $0.5 \mu \mathrm{g} / \mathrm{l}$.

The results obtained with concentrations of $10 \mu \mathrm{g} / \mathrm{l}$ and $0.5 \mu \mathrm{g} / 1$ are represented in Fig. 7. The values obtained with concentrations of $50 \mu \mathrm{g} / 1$ were not higher than those obtained with $10 \mu \mathrm{g} / \mathrm{l}$.

We can note that at a concentration of $10 \mu \mathrm{g} / \mathrm{l}$ in the perfusion medium RP 22410 increased the quantity 
of insulin secreted $(+150 \%)$. A low concentration $[0.5 \mu \mathrm{g} / \mathrm{l}]$ increased the insulin secretion rate by approximately $75 \%$. In these experiments the average insulin secretion rate immediately before the addition of RP 22410 was $28 \mathrm{ng} / \mathrm{min}$ for the first series of experiments and $37 \mathrm{ng} / \mathrm{min}$ for the second series.

The stimulation of insulin secretion was apparent from the start of the administration of the product and persited at the same rate for the entire duration of the infusion. We should note that with both concentrations used, the stimulatory effect on the B-cells persisted (though decreasing in magnitude) for $30 \mathrm{~min}$ after the end of the infusion of RP 22410 .

III. Study of the prolonged administration of RP 22410 on the development of the islets of Langerhans in the mouse

We asked ourselves whether RP 22410 would show (like the other hypoglycaemic sulphonamides already studied) the ability to provoke the development of the islets of Langerhans; particularly the neogenesis of the beta cells (betacytotrophic action). nembutal anaesthesia. The islets of Langerhans were stained in living animals, according to the technique of Haist and Pugh [3]. The technique used has been previously described in detail [11]. The index used for the quantification of the results was the insular index:

area of islets

$\frac{\text { total area of pancreas }}{x} \times$ weight of pancreas in $\mathrm{mg}$ which is directly proportional to the islet weight [11].

\section{B) Results}

The numerical results obtained with the two groups of mice are shown in Table 2. The insular indexes are given first as an absolute value, then per $100 \mathrm{~g}$ of body weight and per $100 \mathrm{mg}$ of pancreas. The comparison between sub-groups was carried out using the insular indices. From the results obtained with group A, it appears that the prolonged administration of $R P$ 22410 orally in daily doses of $2 \mathrm{mg} / \mathrm{kg}$ and $5 \mathrm{mg} / \mathrm{kg}$ increased the weight of islets after 35 days. The average increases were, respectively, $+57 \%$ and $+60 \%$. The subgroups of treated animals differed significantly from the controls $(p<0.01)$; on the other hand there was no significant difference between the behaviour

Table 2. Results of the measurements of the islets in the control mice and the mice treated with RP 22410 at two doses: $2 \mathrm{mg} / \mathrm{kg}$ and $5 \mathrm{mg} / \mathrm{kg}$. (See text)

\begin{tabular}{|c|c|c|c|c|}
\hline \multirow[t]{2}{*}{ MICE } & & \multicolumn{3}{|c|}{ Insular indexes } \\
\hline & & $\begin{array}{l}\text { absolute } \\
\text { values }\end{array}$ & $\begin{array}{l}\text { per } 100 \mathrm{~g} \text { of } \\
\text { body weight }\end{array}$ & $\begin{array}{l}\text { per } 100 \mathrm{mg} \\
\text { of pancreas }\end{array}$ \\
\hline group A & $\begin{array}{l}\text { controls } \\
\text { RP } 224102 \mathrm{mg} / \mathrm{kg} \\
\mathrm{RP} 224105 \mathrm{mg} / \mathrm{kg}\end{array}$ & $\begin{array}{l}0.821 \pm 0.110 \\
1.286 \pm 0.161 \\
1.308 \pm 0.100\end{array}$ & $\begin{array}{l}3.196 \pm 0.425 \\
4.860 \pm 0.566 \\
5.148 \pm 0.408\end{array}$ & $\begin{array}{l}0.311 \pm 0.037 \\
0.489 \pm 0.034 \\
0.529 \pm 0.056\end{array}$ \\
\hline group B & $\begin{array}{l}\text { controls } \\
\mathrm{RP} 224102 \mathrm{mg} / \mathrm{kg} \\
\mathrm{RP} 224105 \mathrm{mg} / \mathrm{kg}\end{array}$ & $\begin{array}{l}1.672 \pm 0.135 \\
2.476 \pm 0.180 \\
2.602 \pm 0.241\end{array}$ & $\begin{array}{l}4.644 \pm 0.365 \\
7.176 \pm 0.678 \\
7.228 \pm 0.670\end{array}$ & $\begin{array}{l}0.467 \pm 0.011 \\
0.688 \pm 0.058 \\
0.691 \pm 0.075\end{array}$ \\
\hline
\end{tabular}

\section{Quantitative study}

\section{A) Technique}

Our experiments were carried out on two groups of Swiss mice; the first consisted of 39 female mice with an initial weight between 20 and $26 \mathrm{~g}$ (group A) (young mice); the second 36 male mice whose initial weight was between 30 and $35 \mathrm{~g}$ (group B) (adult mice). They received a standard balanced diet and water to drink at will. Each group was divided into three subgroups: one sub-group of control mice and two subgroups of test mice which were treated with RP 22410 at two different doses.

The daily doses of RP 22410 were $2 \mathrm{mg} / \mathrm{kg}$ and $5 \mathrm{mg} / \mathrm{kg}$. The product was placed in suspension in a $0.5 \%$ solution of tragacanth and introduced into the stomach by means of an oesophageal tube. The control animals received only the tragacanth solution. In all cases (control and treated groups), the quantity of solution administered was $1 \mathrm{ml} / 100 \mathrm{~g}$ of weight. The experiment lasted 35 days.

The pancreatic tissue was removed in all the animals, $24 \mathrm{~h}$ after the last dose of the product, under of the two subgroups of animals treated by the two doses of $2 \mathrm{mg} / \mathrm{kg}$ and $5 \mathrm{mg} / \mathrm{kg}$.

As for group B, the dose of $2 \mathrm{mg} / \mathrm{kg}$ daily provoked an average increase of the weight of the islets of $+48 \%$, that of $5 \mathrm{mg} / \mathrm{kg}$ daily an average increase of $+56 \%$. The subgroups of treated animals were also in this second series of experiments, significantly different from the controls $(p<0.01)$. Additionally, as in the first series of experiments, there appears no significant difference between the behaviour of the animals treated, respectively, by $2 \mathrm{mg} / \mathrm{kg}$ and $5 \mathrm{mg} / \mathrm{kg}$.

All of these results indicated that prolonged administration of RP 22410 provoked an obvious increase in the mass of the endocrine pancreas. This effect was observed in adult mice and in growing mice as well as in male and female mice. There were no significant differences between the responses to the two doses used: $2 \mathrm{mg} / \mathrm{kg}$ and $5 \mathrm{mg} / \mathrm{kg}$.

\section{Histological study}

The pancreatic sections were examined after fixation in paraffin and stained with haematein and eosin, with fuchsin-paraldehyde, as well as with the 
Gomori-Heidenhain-Azan technique modified by treating the section with a $5 \%$ acetic acid solution before staining with azocarmine.

The betacytotrophic action on the islets of rats treated for 35 days resulted in insular polynesia (increase in the number of islets) as well as hyperplasia (increase in the size of the islets). At the end of the treatment, the islets of Langerhans contained unequally degranulated beta cells. The proportion of alpha cells was not modified in relationship to the controls.

\section{Discussion}

As the results obtained during our experiments on normal dogs have shown, RP 22410 is endowed with a hypoglycaemic action. This effect can be seen whether it is administered intravenously or orally.

In the normal conscious dog, the hypoglycaemic activity of this new sulphonylurea is important since it is on the average, equal to 131 times that of tolbutamide when intravenously given doses are compared on a molar basis.

An interesting property of this substance is its good absorption by the digestive tract. This is shown by an equivalent hypoglycaemic activity when given orally or intravenously and by the appearance of the hypoglycaemic effect rapidly after the administration.

The absence of action of RP 22410 on the blood glucose of totally pancreatectomized dogs suggests that this drug, like the other hypoglycaemic sulphonamides previously studied $[5,6,16]$, acts essentially by its stimulating action on insulin secretion.

This was demonstrated by measuring insulin in the peripheral and in the pancreatico-duodenal blood, in the conscious dog as well as in the anaesthetized animal. The increase of insulin secretion is not a transient phenomenon, it persists several hours. There is an early peak in insulin secretion, afterwards the secretion diminishes, though remaining still higher than the value recorded before the administration of the product.

We should however, ask ourselves whether RP 22410 acted directly on the endocrine pancreas to stimulate it in the same way as did the other hypoglycaemic sulphonamides previously studied $[10,16,12,13]$.

The experiments carried out on the isolated and perfused rat pancreas, show that RP 22410 possesses a stimulating action on the secretion of insulin that is directly exercised on the pancreas. This stimulation appears rapidly and persists during the entire duration of the infusion of the product. After the termination of the infusion, the insulin secretion progressively diminishes but for $30 \mathrm{~min}$ it remains greater than preinfusion level.

The histological examination of the beta cells of the pancreas permitted us to ascertain that RP 22410 provokes their degranulation. RP 22410 therefore possesses a betacytotropic action.
On the other hand, our long-term experiments performed in the mouse, demonstrated that RP 22410 also possessed the ability to stimulate the development of the islets of Langerhans of the pancreas; in particular that of the insulin-secreting cells. Therefore, this product possesses the betacytotrophic properties, in accordance with the terminology previously proposed by Loubatières [7].

The increase of the weight of the islets of Langerhans, verified in the mouse after prolonged administration of RP 22410, is especially important; it is superior to that which we have previously recorded with the other hypoglycaemic sulphonamides in the rat $[8,17,9]$ and in the mouse [11].

Therefore, RP 22410 possesses the pharmacological and pharmacodynamic properties of the hypoglycaemic sulphonamides previously described; however, it belongs to the group of these substances acting at very small doses (second generation hypoglycaemic sulphonamides).

\section{References}

1. Alric, R., Mariani, M.M., Loubatières, A.: Importance de l'état des éléments figurés du sang et en particulier de celui des globules rouges sur les valeurs du glucose sanguin mesurées par l'Auto-Analyseur Technicon. Path. et Biol. 13, 506-511 (1965).

2. Bliss, C.I.: The statistics of bioassay, p. 482-524. Academic Press, N. Y. (1952).

3. Haist, R.E., Pugh, E.J.: Volume measurement of the islets of Langerhans and the effects of age and fasting. Amer. J. Physiol. 152, 36-41 (1948).

4. Hales, C.N., Randle, P.J.: Immuno-assay of insulin with insulin-antibody precipitate. Biochem. J. 88, $137-146$ (1963)

ธ. Loubatières, A.: Analyse du mécanisme de l'action hypoglycémiante du p-amino-benzène-sulfamido-isopropyl-thiodiazol (2254 RP) C.R. Soc. Biol. 138, $766-767$ (1944).

6. - Physiologie et pharmacodynamie de certains dérivés sulfamidés hypoglycómiants. Contribution à l'étude des substances synthétiques à tropisme endocrinien. Thèse Doctorat ès-Sciences Naturelles, Montpellier, 1er juin 1946, $\mathrm{n}^{\circ} 86,93$ pages, 16 figures, Causse, Graille et Castelnau édit. (1946).

7. - I. Analyse de l'action bêta-cytotrope des sulfamides hypoglycémiants. II. Analyse de l'action anti-diabétique des sulfamides hypoglycémiants. La Presse Médicale 68, 1421-1424 et 1441-1444 (1960).

8. - Fruteau de Laclos, C., Houareau, M.H.: Etude quantitative de la néogénèse des îlots de Langerhans du pancréas, provoquée par un sulfamide hypoglycémiant, le tolbutamide. C.R. Soc. Biol. 157, 1652-1654 (1963).

9. - Mariani, M.M., Alric, R.: Actions respectives ou simultanées du tolbutamide et du diazoxide sur le développement des îlots de Langerhans. C.R. Acad. Sci., 265, série D, 2127-2131 (1967).

10. - - - Chapal, J.: Antagonistic mechanism of actions of tolbutamide and diazoxide on insulin secretion. In "Tolbutamide after ten years". BrookLodge Symposium 6-7 mars 1967, Congress series $n^{0} 149$, p. $100-113$. Excerpta Medica Foundation (1967). 
11. - - - Ribes, G., de Malbosc, H., Houareau, M.H.: Etude expérimentale d'un nouveau sulfamide hypoglycémiant particulièrement actif, le HB 419 ou glibenclamide. II. Action bêtacytotrophe et stimulatrice de la néogénèse des îlots de Langerhans. Diabetologia 5, 219-227 (1969).

12. - - Chapal, J.: Etude physiologique et pharmacologique de l'insulino-sécrétion. I. Effet du glucose et des sulfamides hypoglycémiants. J. Pharmacologie (Paris) 1, 7-24 (1970).

13. - - - Insulino-sécrétion étudiée sur le pancréas isolé et perfusé du rat. I. Synergie entre glucose et sulfamides hypoglycémiants. Diabetologia 6, 457-466 (1970).

14. - - Ribes, G.: Pharmacologie et pharmacodynamie d'un sulfamide hypoglycémiant très actif sur l'insulino-sécrétion et la néogénèse des cellules bêta des îlots de Langerhans pancréatiques. C.R. Ac. Sc., série D, 271, 1446-1447 (1970).
15. - - - Analyse expérimentale du 4-\{4-\{ $\beta$-(5-méthylisoxazole-3-carboxamido)-éthyl -benzol-sulfonyl) - 1,1hexamóthylène-semicarbazide (RP 22410 ou BS 4231). Abstract Diabetologia 6, 638 (1970).

16. - - - de Malbose, H., Chapal, J.: Etude experimentale d'un nouveau sulfamide hypoglycémiant particulièrement actif le HB 419 ou glibenclamide. I. Action bêtacytotrope et insulino-sécrétrice. Diabetologia 5, 1 - 10 (1969).

17. - Taylor, J., Houareau, M.H., Alric, R.: Activité néogénétique pour les îlots de Langerhans du benzènesulfamido-tertiobutyl-thiodiazol. C.R. Soc. Biol. 159, $156-158(1965)$.

Professeur A. Loubatières, Faculté de Médecine, Laboratoire de Pharmacologie et Pharmacodynamie, Institut de Biologie, F-34 Montpellier, France 